\title{
La Formation d'une Littérature Populaire Bantoue.
}

UNE question qu'il convient d'envisager hardiment, parce qu'elle ne saurait être esquivée plus longtemps, est celle des mesures à prendre pour mettre à la disposition de la masse des indigènes évolués une littérature instructive et récréative, en concordance avec leur mentalité. La solution qui s'impose est d'adapter à des buts éducatifs leur propre trésor de style oral. Il est à remarquer à ce sujet, qu'en annotant durant des années des fables, des légendes, des dictions, des proverbes, les missionnaires semblent avoir entrevu de tout temps la haute signification que ce patrimoine littéraire avait pour leur œuvre de civilisation. Aussi leur travail nous a-t-il valu une première codification, partielle et sporadique, de la littérature orale indigène.

En présence des modifications profondes, qui aujourd'hui se font jour au sein de la société indigène, il y a urgence à ce qu'on sauve d'une perte irrémédiable cette abondance de ressources littéraires. Ce qui a été fait jusqu'ici dans ce sens, souvent avec patience et ténacité, constitue un travail de longue haleine, que la technique moderne permet de réaliser à un rythme accéléré et dans des conditions scientifiques plus satisfaisantes. Le Bulletin des Séances de l'Institut Royal Colonial Belge publie dans son dernier numéro (vi, 1935, 7) les résultats d'une expérience, qui est décisive en cette matière.

Subventionné par l'institut en vue d'enregistrer des chants indigènes, le R.P. Van Bulck y fit récemment un rapport sur sa mission d'études chez les Bakongo orientaux. La difficulté de l'entreprise était grande, et le rapporteur en l'exposant avoue ' qu'elle était même plus grande qu'il ne l'avait soupçonnée'. Pendant un séjour de neuf mois dans la région, il a pu enregistrer néanmoins 72 disques, qui sont arrivées sans dommages en Europe. Les chants les plus divers ont été enregistrés: des mélopées funéraires, des chansons de travail, des chansons de féticheur et de sorcier, des chansons d'incantation de fétiches, des chansons d'initiation, des chansons de femme pour endormir l'enfant, des chansons d'hommes qui boivent le malafu, des chansons de danse, des chansons de marché, etc. En outre il a pu recueillir plus de 800 légendes dont certaines de plus de ro pages in-quarto, plus de I,I00 proverbes et devinettes, plus de 900 chansons, strophes et refrains rythmés. Indépendamment de l'intérêt que cette riche documentation présente au point de vue linguistique et ethnographique, elle permet comme le R.P. Van Bulck se le propose - 'd'en reproduire les plus beaux morceaux et d'en faire des recueils de lecture tribale pour les jeunes Bakongo'. (Communiqué par M. le Professeur N. De Cleene, Université d'Anvers.)

\section{The 'Best Friend' in Dahomey.'}

Even that delicate and elusive matter of which human friendship is built can crystallize in a definite social institution; and in this article is described the

I By Melville J. Herskovits, in Negro, an Anthology by Nancy Cunard. 
form of institutionalization which moulds friendship in Dahomean society. Institutionalized friendship appears to reflect in its own fashion the general tendency of the society, and even of West African negro culture at large, towards highly developed organization. The most interesting feature lies naturally in the solution of the problem of how the elastic personal relationship and the more rigid structure of the social institution can be made to blend. The institution of friendship in Dahomey combines cleverly confidence in the chosen friend and lack of reservation based on complete mutual esteem and understanding, with certain fixed duties and social obligations which are implied in the official relationship of 'best friends'. This relationship, deeply seated as it is, is also illustrated in the folk-tales of the tribe. The Dahomeans distinguish three types, or rather three grades, of friendship which are marked by different names, and which entail different forms, or degrees, of personal relationship and intimacy. They often originate from different sources: the friendship of the 'best friend' arises as a rule out of early playmate relationship; the 'second-best' or 'third-best' friendship on the other hand would originate in the circumcision groups, in the 'mutual aid societies', and such like. Yet in this outspoken hierarchy of friends a form of promotion is possible, and the "second-best friend" may become the 'best friend' of a man whose original 'best friend' has died.

Friendship in this institutionalized form is almost obligatory for the adult; it does not, however, cross the barrier of sex. The association which it establishes is common knowledge in the social milieu of the people concerned. Yet only on certain ceremonial occasions, at funerals and marriage-ceremonies, does it manifest itself publicly. Here the 'best friend' plays the prominent part. He is, for instance, in the case of a man's death the one who knows all about the property left; he would be among the heirs himself, and to him the deceased man would have entrusted his last will; he would finally be the leader, and protagonist at the same time, of the complicated ceremonial prescribed by tradition. Apart from this ceremonial obligation the 'best friend' is the one person you can rely on implicitly even in cases when the help which you expect from him may run counter to tribal law or rules of tradition, as in the case of a secret elopement or an escape from the king's officers. I may, in conclusion, endorse from my own knowledge of a West African tribe the author's surmise that this type of formalization of friendship exists in other parts of Africa as well. It would certainly be one of the most profitable tasks to compare the various forms, and for that matter degrees, of institutionalization in which friendship appears organized in certain related culture areas of West Africa, in correlation to the general forms of social organization in which they are embedded. (Communicated by DR. S. F. NADEL, Research Fellow of the Institute.) 